\title{
A Study of Association between Taiwan's Corporate Governance Appraisal and Financial Performance: Evidence from Taiwan Listed Companies
}

\author{
Li-Lun Liu ${ }^{1}$, Yu-Ting Huang ${ }^{2}$ \\ ${ }^{1}$ Department of Business Administration and Department of Accounting College of Business, Chung Yuan \\ Christian University, Chung-li City, Taiwan \\ ${ }^{2}$ Department of Finance, MingDao University, Changhua City, Taiwan \\ Correspondence: Yu-Ting Huang, Department of Finance, MingDao University, Changhua City, Taiwan.
}

Received: July 3, 2019

doi:10.5539/ibr.v12n11p66

\begin{abstract}
To enable all listed companies to gradually upgrade and implement corporate governance, the appraisals are promoted to assist investors through the comparison of corporate governance appraisal (CGA) in Taiwan's market. Using a panel data is based on the companies listed on the Taiwan Stock Exchange during the period 2014-2016; this paper provides evidence that earnings management is affected negatively by corporate governance quality.

This is expected to guide healthy competition between enterprises and strengthen corporate governance. Recent studies have pointed out that managers are more favorable to their actions due to weak corporate governance. While most studies explored the relationship between corporate governance and financial performance, few studies have included in corporate governance appraisal (CGA).

This study examines how CGA in Taiwan listed companies will affect their earnings quality and this study uses earnings management (EM) as measure of financial performance. In addition, reference is made to the Big 4 accounting firms to explain the consequences of CGA and, specifically, its effect on the quality of financial statements. The empirical results show that CGA and earnings management have a significantly negative correlation. In addition, the CGA of companies audited by the Big 4 indicate that those with better earnings quality also conduct less earnings management.
\end{abstract}

Keywords: corporate governance appraisal, earnings management, big 4 accounting firms

\section{Introduction}

To draw level with the rapid global development of corporate governance appraisal (CGA), the Financial Supervisory Commission (FSC) has actively promoted corporate governance policies from the government to the private sector in recent years and is expected to accelerate the promotion of corporate governance on the companies listed on the Taiwan Stock Exchange. The FSC conducted its first CGA in 2014 ${ }^{1}$. Information disclosure by Taiwan listed companies is an important part of corporate governance. Enterprises are encouraged to enhance information transparency and convenience, thereby improving the overall quality of information disclosure in Taiwan's capital market and increasing the value of enterprises through investors' rights. To build a financial environment that is internationally competitive, Taiwan established the "Financial Reform Task Group" in July 2002. Since 2003, the Taiwan Stock Exchange (TWSE) and Taipei Exchange (TPEx) have been commissioned by the Securities and Futures Institute to implement the "Information Disclosure Appraisal System." However, the two evaluation systems have been consolidated since 2015 in view of the important indicators of the "Information Disclosure Appraisal" in corporate governance appraisal (CGA), thereby improving the efficiency of the evaluation work and avoiding duplication of work. Following the results of the

\footnotetext{
${ }^{1}$ Corporate Governance Appraisal - Corporate Governance Center. http://cgc.twse.com.tw/evaluationCorp/listCh
} 
$12^{\text {th }}$ disclosure assessment in 2015 , it will not renew the related operations. ${ }^{2}$

In terms of promoting corporate governance in Taiwan, many related concepts have been gradually codified and released in accordance with the development trend of international corporate governance in the "2013 Strengthen the Blue-print Plan for corporate governance in Taiwan," prompting relevant units to complete many measures. It was required that by 2017 , all listed companies would have independent directors with greater participation, and an expanded audit committee. Listed companies were encouraged to set corporate governance units and assign high-level supervisors to supervise. In addition, the 2016 "Asian Corporate Governance Report: Evaluation Report" mentioned that the corporate governance culture of Taiwan still mostly adopts a top-down approach and expected Taiwan's companies' future efforts to encourage domestic institutional investors to upgrade listed companies. At the governance level, the report stated that Taiwan's companies will continue to strengthen their boards of directors and compensation information, expand the disclosure of English information, and promote case-by-case voting.

This study explores the relationship among corporate governance, financial performance, and this study uses earnings management (EM) as measure of financial performance. To help investors and companies understand the effectiveness of corporate governance, Taiwan's companies have been conducting CGA since 2014. Effective appraisals guide the healthy competition of enterprises and, thus, improve the overall level of corporate governance in Taiwan. Although Taiwan's companies have progressed in their implementation of corporate governance, the promotion of CGA is a path of no progress and no response. The dynamic state of global markets has accelerated the promotion of internationally accepted corporate governance systems in Taiwan. It is hoped that the blueprint will encourage companies to voluntarily implement corporate governance and encourages external investors, such as institutional investors, to actively participate in corporate governance and thereby enhance the international competiveness of Taiwan's capital market.

This study examines how CGA on the companies listed on the Taiwan Stock Exchange will affect their earnings quality and this study uses earnings management as measure of financial performance. In addition, reference is made to the Big 4 accounting firms to explain the consequences of CGA and, specifically, its effect on the quality of financial statements. Past studies have found which were audited by one of Big Four audit (a proxy for audit quality) will have a better market performance as well as greater transparency (Mitton 2002), thus, when auditing the financial statements, errors and lack of internal controls in financial supervision were better identified and this resulted in better financial statements. The empirical results show that CGA and earnings management have a significantly negative correlation. In addition, the CGA of companies audited by the Big 4 indicate that those with better earnings quality also conduct less earnings management.

This study examines how CGA of Taiwan listed companies affects their earnings quality. Therefore, this study calculates earnings management as measure of financial performance. In addition, in order to determine its nature and understand its causes and consequences, this study also examines how the CGA affects earnings management under the Big 4 accounting firms. Chapter 2 presents a discussion of the literature and hypothesis development. Chapter 3 explains the research framework, sources of data, and the design of the empirical model. The fourth chapter presents results of the narrative statistics and empirical analysis, and the last chapter discusses the results and concludes the paper.

\section{Literature Review and Hypothesis Development}

The purpose of this study is to explore the corporate governance appraisal and the financial information provided by it to calculate the discretionary accrual as measure of earnings management. Therefore, this chapter explores relevant literature as the basis for this study. Schipper (1989) stated that earnings management is the use of external reports to conduct purposeful manipulations in order to achieve the intentions of managers that seek personal benefits. It can be seen that when managers conduct earnings management behavior, there will be incentives for earnings management and use of earnings management tools to enable them to manipulate financial information (Lel and Miller.2008; Defond and Hung 2004; Volpin 2002; Allgood and Farrel 2000). This will enable managers to use earnings management to influence the company's financial performance. In addition, reference is made to the Big 4 accounting firms to explain the consequences of CGA and, specifically, its effect on the quality of financial statements, thus, the Big 4 audit firm dummy presents a positive performance effect. This implies that the accounting and audit quality of the firm is one of the vital control mechanisms to protect the interest of outside shareholders (Omar et al. 2007)

\footnotetext{
${ }^{2}$ Taiwan Stock Exchange (TWSE), Corporate Governance Center, Information Disclosure Introduction https://cgc.twse.com.tw/front/evaluationInfoOverview
} 
The financial statements provided by the company are intended to provide effective financial information for immediate and reliable delivery to external users, such as investors, creditors, etc., because managers can improve the effectiveness of financial statements through professional competence. Thus, managers have the opportunity to adjust the financial statements. Because managers have discretion over accounting choices, they have an incentive to present misrepresented financial statements to users.

If a company is making loss or its earnings are lower than expected, the company has the motivation to manipulate reported earnings and thereby appear to achieve the performance threshold, dress-up financial statements, and confirm manager's salary. When the degree of linkage between accounting performance and financial performance is higher, the degree to which managers perform earnings management will be relatively high. Watts and Zimmerman (1978) proposed three motivations for earnings management by managers: debtequity hypothesis, dividend plan hypothesis, and scale hypothesis.

In addition, Healy and Wahlen (1999) have also collated the literature on earnings management, defining earnings management as the discretion of managers to adjust financial statements, or to affect contractual outcomes that rely on accounting figures. In general, managers can use the following methods to adjust the following: (1) accounting estimates; (2) choice of accounting methods; (3) working capital management; and (4) accounting for or deferring accounts.

Past studies have found that companies engaged in earnings management have poor corporate governance, high financial leverage, and financial difficulties ${ }^{3}$. If the proportion of independent directors of the company is higher, it will reveal better earnings quality. When the company's financial statements are less transparent, it will lead to poor corporate governance, and the management will find the behavior of earnings manipulation to not be optimum. If it has been found that there will be an increase in the company's share price, then there will be a strong incentive for earnings management (Hunton et al. 2006; Klein 2002).

To accelerate the promotion of corporate governance in listed companies in Taiwan, assist enterprises in sound development, and enhance market confidence, the Financial Supervisory Commission (FSC) issued a five-year "Strengthen the Blue-print Plan for corporate governance in Taiwan" in December 2013 under which CGA will be conducted. It is listed as a key work item in 2014 and, therefore, the sample period for the study is 20142016. The reason for the promotion is to help investors and enterprises understand the effectiveness of corporate governance implementation through comparison of corporate governance systems in the overall market. It is also expected that this evaluation system can guide healthy competition among enterprises, strengthen corporate governance to further shape enterprises, and proactively improve the culture of corporate governance. CGA is conducted annually. The full year of corporate governance in the previous year (i.e., the year of assessment from January 1 to December 31) is the scope of assessment. In addition, there are also relevant institutions for CGA that are worthy of reference, CLSA and S\&P. Taiwan also has many CGA agencies such as the Taiwan Governance Association and CGA.

This study examines how the CGA of Taiwan listed companies affects their earnings quality. Therefore, this study calculate earnings management as measure of financial performance provided as measure of financial performance and discusses the relationship between CGA and earnings management. In addition, to help investors and companies understand the effectiveness of corporate governance implementation, this study also examines how CGA affects earnings management under the Big 4 accounting firms in order to determine their nature and to understand their causes and consequences. Therefore, this leads to the following hypothesis is developed:

H1: Corporate governance appraisal is associated with earnings management

$\mathrm{H} 2$ : The negative relationship between corporate governance appraisal and earnings management for Big 4

\section{Research Method}

\subsection{Sample Selection}

The empirical analysis of this study used the reference literature to develop the research design, collect relevant research variables and literature, establish an empirical model, and adopt appropriate data analysis methods. This study is based on company listings of the Taiwan Stock Exchange (TWSE) from 2014 to 2016 and explores the

\footnotetext{
${ }^{3}$ Abbadi et al. (2016) provided evidence that earnings management are affected negatively by corporate governance quality; The companies have good corporate governance practices can improve management performance in supervising or monitoring the management performance (Shan 2015; Dalimunthe et al. 2016; Lubis et al. 2016; Muda et al. 2016).
} 
impact of the relationship between CGA and earnings management. Data sources are CGA, the TWSE Corporate Governance Center, and the financial database of the Taiwan Economic Journal (TEJ). CGA is conducted annually. The full year of corporate governance in the previous year (i.e., the year of assessment from January 1 to December 31) is the scope of assessment. The first evaluation was conducted for the full year of 2014. To enable all listed companies to gradually upgrade and implement corporate governance, the appraisal results are published year-by-year as follows: In 2015, announced the results of the first CGA and the top 20\% of enterprises; in 2016, announced the results of the second corporate governance review and announced the top $50 \%$ of companies.

Table 1 describes the sample distribution for Taiwan listed companies Panel A of Table 1 presents the annual distribution of research samples, showing that the proportion of CGA is about $87.17 \%(2,405 / 2,759)$, which is non-CGA, accounting for $12.83 \%$ (354/2,759). In addition, the number of samples subject to CGA is increasing year-by-year. This is due to the inclusion of CGA as a key work item in 2014. Through the comparison of corporate governance systems in the overall market, enterprises are expected to be more focused on corporate governance and guidance, thereby improving competitiveness, strengthening corporate governance, and further shaping the companies' initiative to improve corporate governance. Panel B further differentiates the Big 4 accounting firms, showing that the majority of companies subject to CGA by diligent public trust accounted for $31.79 \%(877 / 2,759)$ of the Deloitte sample.

\subsection{Research Design and Empirical Proxies}

\subsubsection{Empirical Models}

This study describes how corporate governance appraisal (CGA) in Taiwan listed companies will affect their earnings quality and this study uses earnings management (EM) as measure of financial performance for probing linear models and introduces macros for STATA statistical software to simplify the computations in ordinary least squares (OLS) and logistic regression. A research model is constructed to examine whether the selection of Corporate Governance Appraisal is associated with earnings management. The research model (1) is as follows:

$$
\begin{gathered}
E M_{i, t}=\alpha_{0}+\alpha_{1} \text { ESTIMATE }_{i, t}+\alpha_{2} \text { GROWTH }_{i, t}+\alpha_{3} \text { ROA }_{i, t}+\alpha_{4} \text { LEV }_{i, t}+\alpha_{5} \text { QUICK }_{i, t}+\alpha_{6} \text { INDBOD }_{i, t} \\
+\alpha_{7} \text { LOSS }_{i, t}+\varepsilon_{i, t},
\end{gathered}
$$

where:

$E M$

$C G A$

GROWTH

$R O A$

$L E V$

QUICK

INDBOD

LOSS
$=$ earnings management;

$=1$ if the company has CGA and 0 otherwise;

$=$ revenue growth rate;

$=$ return on assets ;

$=$ debt ratio;

$=$ quick ratio ;

$=$ independent director ratio;

$=1$ if the company has loss and 0 otherwise.

Table 1. Sample Distribution

Panel A : Yearly Distribution by corporate governance appraisal(CGA) and Non-corporate governance

\begin{tabular}{|c|c|c|c|}
\hline $\begin{array}{ll} & \text { Tyoe } \\
\text { Year }\end{array}$ & CGA & Non-CGA & Total \\
\hline 2014 & 258 & 120 & $378(13.70 \%)$ \\
\hline 2015 & 674 & 111 & $785(28.45 \%)$ \\
\hline 2016 & 1,473 & 123 & $1,596(57.85 \%)$ \\
\hline Total & 2,405 & 354 & 2,759 \\
\hline Percentage (\%) & $87.17 \%$ & $12.83 \%$ & $100 \%$ \\
\hline
\end{tabular}
appraisal(Non-CGA)

\begin{tabular}{|c|c|c|c|c|c|c|c|c|c|c|c|}
\hline & \multicolumn{4}{|c|}{ CGA } & \multicolumn{7}{|c|}{ Non-CGA } \\
\hline & $\begin{array}{c}\text { Deloitt } \\
\mathrm{e}\end{array}$ & PWC & KPMG & EY & 小計 & $\begin{array}{c}\text { Deloitt } \\
\mathrm{e}\end{array}$ & PWC & $\begin{array}{c}\text { KPM } \\
\text { G }\end{array}$ & EY & $\begin{array}{c}\text { Subtota } \\
1\end{array}$ & Total \\
\hline 2014 & 94 & 69 & 57 & 27 & 258 & 25 & 25 & 25 & 14 & 120 & 378 \\
\hline 2015 & 245 & 165 & 127 & 84 & 674 & 38 & 19 & 17 & 12 & 111 & 785 \\
\hline 2016 & 538 & 352 & 288 & 158 & 1,473 & 42 & 26 & 18 & 14 & 123 & 1,596 \\
\hline Total & 877 & 630 & 427 & 269 & 2,405 & 105 & 70 & 60 & 40 & 354 & 2,759 \\
\hline $\begin{array}{c}\text { Percentag } \\
\text { e }(\%)\end{array}$ & $31.79 \%$ & $\begin{array}{r}22.83 \\
\%\end{array}$ & $\begin{array}{r}15.48 \\
\%\end{array}$ & $\begin{array}{r}9.75 \\
\%\end{array}$ & $\begin{array}{r}87.17 \\
\%\end{array}$ & $3.81 \%$ & $\begin{array}{r}2.54 \\
\%\end{array}$ & $2.17 \%$ & $\begin{array}{r}1.45 \\
\%\end{array}$ & $12.83 \%$ & $\begin{array}{r}100.00 \\
\%\end{array}$ \\
\hline
\end{tabular}

Panel B: Distribution of Big 4 accounting firms

Note. The FCC handles the first corporate governance appraisal in 2014, so that all listed companies can gradually upgrade and implement corporate governance. 


\subsection{Related Variables and Operational Definitions}

\subsubsection{Dependent Variable: Earnings Management}

In accounting, earnings can avoid the problem of measuring cash flow; thus, earnings are considered as an indicator to measure the company's financial performance. However, under general accounting principles, there is some degree of flexibility such that the adjudicating accruals become the judgment of the company's management. One of the most common and inconspicuous methods in earnings management is the accruals method. In addition, accruals can reflect the net result of the company's manipulation of earnings; therefore, this study uses accruals to measure earnings management and, hence, the financial performance of the company. There are many ways to measure earnings management by accruals. Among them, Rangan (1998) considered the use of discretionary current accruals to detect the company's earnings management behavior to be the best and the detection capability of the Modified Jones Model to be better.

The Jones Model (1991) and Modified Jones Model (1995) are the most widely used measures of earnings management. As for the estimated part of the adjudicative accruals, this study refers to the past literature. The Modified Jones Model proposed by Dechow et al. (1995) estimates non-decisive accruals as a proxy variable for corporate earnings management. The term "Total Accruals" refers to the difference between the calculated earnings on the accrual basis and the earnings calculated on the cash basis, the difference between the net profit and cash flow of the business activity. The value includes all accounting choices under the accrual basis so that the total accrual item can be used as a choice to explore whether the company intends to manipulate the accounting method to achieve a specific motivation.

\subsubsection{Independent Variable: Corporate Governance Appraisal}

The FCC handled the first corporate governance appraisal in 2014. In order to enable all listed companies to gradually upgrade and implement corporate governance, the reason for the promotion is to help investors and companies through the comparison of corporate governance in the overall market. Understanding the effectiveness of corporate governance implementation can also lead to healthy competition between companies and strengthen corporate governance.

\subsubsection{Control Variables}

This study refers to past related research and adds the control variables revenue growth rate $(G R O W T H)$, return on assets $(R O A)$, debt ratio (LEV), quick ratio (QUICK), independent director ratio (INDBOD), and loss (LOSS). Past research has revealed that the higher the profitability level required, the greater the incentive to engage in earnings management (e.g., Kothari et al. 2005). This is because when the company is growing at a profitable level (higher profits), the surplus will expand. For earnings management, in order to control the impact of total return on equity on earnings management, this study uses the return on total assets $(R O A)$ as the measure of profitability and expects the direction of the $R O A$ coefficient to be positive. The larger the company and the more the types and amounts of earnings management, the more likely is the management to use earnings management to stabilize the company's current year's surplus (Reynolds and Francis 2000). DeAngelo et al. (1994) pointed out that when the company's debt ratio is higher, in order to avoid financial crisis, managers have incentives to increase the company's reported earnings. DeFond and Jiambalvo (1994) also pointed out that the debt ratio of companies that violated debt contracts was significantly higher and that these companies had positive abnormalities; thus, the estimated debt ratio was positively correlated with the abnormal accruals. Warfield et al. (1995) also found that the debt ratio was positively correlated with the anomaly accruals. Therefore, the study included the debt ratio $(L E V)$ as the control variable and expected the coefficient direction to be positive.

\section{Empirical Results}

\subsection{Descriptive Statistics}

Table 2 reports the statistical data. To understand the basic differences between total samples and CGA and non-CGA, we first observe $E M, C G A$, revenue growth rate $(G R O W T H)$, return on assets $(R O A)$, debt ratio ( $L E V)$, quick ratio ( $Q U I C K)$, independent director ratio (INDBOD), and loss (LOSS), which show that companies with a CGA finding lower EM have a higher return on total assets, lower debt ratio, and better independent directors. In other words, companies using CGA can effectively suppress earnings management and improve their financial performance. 
Table 2. Descriptive Statistics

\begin{tabular}{|c|c|c|c|c|c|c|c|c|c|}
\hline \multirow[b]{2}{*}{$\begin{array}{l}\text { Variab } \\
\text { les }^{\text {a }}\end{array}$} & \multicolumn{3}{|c|}{ Total sample $(n=2,759)$} & \multicolumn{3}{|c|}{ CGA $(n=2,405)$} & \multicolumn{3}{|c|}{ Non-CGA $(n=354)$} \\
\hline & Mean & Median & Std. Dev & Mean & Median & Std. Dev & Mean & Median & Std. Dev \\
\hline$E M$ & -0.0292 & -0.0326 & 0.1124 & -0.0308 & -0.0325 & 0.0797 & -0.0174 & -0.0323 & 0.2351 \\
\hline$C G A$ & 0.8716 & 1.0000 & 0.3344 & 1.0000 & 1.0000 & 0.0000 & 0.0000 & 0.0000 & 0.0000 \\
\hline $\begin{array}{l}\text { GROW } \\
T H\end{array}$ & 0.1315 & 0.0041 & 2.3381 & 0.1125 & 0.0043 & 2.4185 & 0.2605 & 0.0035 & 0.6915 \\
\hline$R O A$ & 0.0789 & 0.0773 & 0.1014 & 0.0871 & 0.0802 & 0.0846 & 0.0231 & 0.0408 & 0.1671 \\
\hline$L E V$ & 0.3014 & 0.2759 & 0.1730 & 0.2898 & 0.2668 & 0.1636 & 0.3800 & 0.3574 & 0.2110 \\
\hline QUICK & 2.2490 & 1.3186 & 6.4606 & 2.2211 & 1.3533 & 6.1826 & 2.4387 & 1.0118 & 8.1090 \\
\hline $\begin{array}{l}I N D B O \\
D\end{array}$ & 0.2997 & 0.2857 & 0.1327 & 0.3003 & 0.2857 & 0.1299 & 0.2955 & 0.3333 & 0.1507 \\
\hline LOSS & 0.1964 & 0.0000 & 0.3974 & 0.1950 & 0.0000 & 0.3962 & 0.2062 & 0.0000 & 0.4051 \\
\hline
\end{tabular}

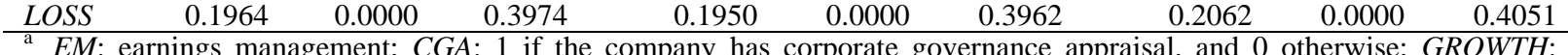
revenue growth rate; $R O A$ : return on assets; $L E V$ : debt ratio; $Q U I C K$ : quick ratio; INDBOD: independent director ratio; LOSS: 1 if the company has loss, and 0 otherwise.

\subsection{Correlation Matrix}

This study analyzes the Pearson correlation matrix for the research variables. Pearson correlation is used to characterize the correlation between variables and to explore the direction and extent of influence between variables as shown in Table 3. The analysis reported in Table 3 shows that $E M$ is significantly negatively correlated with $C G A$ (correlation coefficient is -0.039), representing companies with CGA, which have lower earnings management and better financial performance. In addition, $E M$ is positively correlated with revenue growth rate $(G R O W T H)$, total return on assets $(R O A)$, and debt ratio $(L E V)$, indicating that companies with higher debt ratios will have higher motivation of earnings management. However, there is a positive correlation with loss (LOSS), but it is not significant. In addition, the independent director ratio (INDBOD) relationship showed a significant negative correlation.

Table 3. Correlation Matrix

\begin{tabular}{|c|c|c|c|c|c|c|c|c|}
\hline Variables $^{\text {a,b }}$ & $E M$ & $C G A$ & GROWTH & $R O A$ & $L E V$ & QUICK & INDBOD & LOSS \\
\hline$E M$ & 1.000 & & & & & & & \\
\hline$C G A$ & $-0.039 *$ & 1.000 & & & & & & \\
\hline GROWTH & $0.059 *$ & -0.021 & 1.000 & & & & & \\
\hline$R O A$ & $0.074 *$ & $0.211 *$ & -0.021 & 1.000 & & & & \\
\hline$L E V$ & $0.046^{*}$ & $-0.174 *$ & 0.032 & $-0.100 *$ & 1.000 & & & \\
\hline$Q U I C K$ & 0.024 & -0.011 & $0.055^{*}$ & $-0.068 *$ & $-0.249 *$ & 1.000 & & \\
\hline$I N D B O D$ & $-0.068 *$ & 0.012 & $-0.042 *$ & $0.109^{*}$ & -0.032 & 0.031 & 1.000 & \\
\hline LOSS & 0.002 & -0.009 & 0.021 & 0.014 & -0.008 & -0.017 & $-0.044 *$ & 1.000 \\
\hline
\end{tabular}

\subsection{Multivariate Analysis}

\subsubsection{Corporate Governance Appraisal and Earnings Management}

This study is intended to understand whether Taiwan listed companies have CGA that have lower earnings management, thereby reducing the manipulation of their earnings and resulting in better financial performance. In addition, the Big 4 accounting firms are responsible for the audit of $88.91 \%$ of Taiwan listed companies (the statistics are provided by Taiwan Economic Journal, 2016), Table 4 presents regression results for hypothesis 1 , and Table 4 divides the sample into total samples, the Big 4 accounting firms and non-Big 4 accounting firms. The empirical results show total samples and the Big 4 accounting firms have CGA, with estimated coefficients of $-0.0167(t=-2.53)$ and $-0.0068(t=-1.74)$, respectively. The results are all significantly negatively correlated, as predicted by hypothesis 1 . In addition, the sample companies having CGA are checked by the non-Big 4 accounting firms; although they reached a negative level, it is not significant. Companies audited by the Big 4 accounting firms have significantly higher earnings value compared with those audited by non-Big 4 accounting firms, due to better audit quality of Big 4 accounting firms. Hence, they are better able to curb 
earnings management and reduce the risk of significant fraud in financial statements, thereby increasing the positive impact of audit quality on financial performance, as predicted by hypothesis 2 .

In addition, since the Enron case and revision of the Certified Public Accountant Law, the accountability of accountants has been aggravated and the supervision of competent authorities has been strengthened. Auditors of the Big 4 accounting firms have become more conservative in their audit judgments, which will help improve the overall quality of inspections and, thereby, reduce incentives for earnings management by managers.

In terms of control variables, revenue growth rate (GROWTH), total return on assets (ROA), debt ratio (LEV), and quick ratio $(Q U I C K)$ are significantly positive in total samples and the Big 4 accounting firms, whereas independent directors $(I N D B O D)$ showed significantly negative correlation. Companies with higher revenue growth rate $(G R O W T H)$ and total return on assets $(R O A)$ due to higher asset utilization efficiency may have more controllable space for increasing income and capital use, thus there is higher earnings management. The debt ratio $(L E V)$ and the quick ratio $(Q U I C K)$ are significantly positively correlated, showing the company's ability to pay off short-term liabilities. When the liquidity is higher, the company also has incentives for surplus control. The proportion of independent directors $(I N D B O D)$ is significantly negatively correlated, indicating that when the number of independent directors is large, the company's internal mechanism is better, and it can better suppress earnings management.

Table 4. Corporate Governance Appraisal and Earnings Management

\begin{tabular}{|c|c|c|c|c|c|c|c|}
\hline \multirow[b]{2}{*}{ Variables $^{a}$} & \multirow[b]{2}{*}{$\begin{array}{l}\text { Pred. } \\
\text { Sign }\end{array}$} & \multicolumn{2}{|c|}{ Total sampl } & \multicolumn{2}{|c|}{ Big 4 accounting firms } & \multicolumn{2}{|c|}{ Non-Big 4 accounting firms } \\
\hline & & Coef. & $t$-value ${ }^{b}$ & Coef. & $t$-value & Coef. & $t$-value \\
\hline CONSTANT & & -0.0169 & $-1.81^{*}$ & -0.0098 & $-2.21 * *$ & -0.0143 & -0.46 \\
\hline$E M$ & - & -0.0167 & $-2.53 *$ & -0.0068 & $-1.74 * *$ & -0.0250 & -1.04 \\
\hline GROWTH & $?$ & 0.0025 & $2.80 * * *$ & 0.0009 & $1.79 *$ & 0.0188 & $3.46 * * *$ \\
\hline$R O A$ & ? & 0.1133 & $5.26 * * *$ & 0.0222 & $4.64 * * *$ & 0.2476 & $2.92 * * *$ \\
\hline$L E V$ & $?$ & 0.0354 & $2.73 * * *$ & 0.0129 & $2.27 * *$ & 0.0675 & 1.31 \\
\hline QUICK & $?$ & 0.0008 & $2.20 * *$ & 0.0004 & $2.18 * *$ & 0.0010 & 0.88 \\
\hline INDBOD & $\dot{?}$ & -0.0646 & $-4.01 * * *$ & -0.0163 & $-3.64 * * *$ & -0.0692 & -1.10 \\
\hline LOSS & ? & -0.0001 & -0.02 & 0.0053 & 0.03 & 0.0021 & 0.09 \\
\hline Adj. $R^{2}$ & & $1.90 \%$ & & $1.46 \%$ & & $5.50 \%$ & \\
\hline Nobs. & & 2,759 & & 2,453 & & 306 & \\
\hline
\end{tabular}

\subsubsection{Corporate Governance Appraisal and Earnings Management: Big 4 Accounting Firms and Non-Big 4} Accounting Firms

Brian et al. (2012) mean that the Big Four international accounting firms are among the market leaders for providing assurance for services across the full spectrum of sustainability advisory and assurance engagements such as sustainability reporting. The empirical results reported in Table 4 indicate that companies that have been audited by the Big 4 accounting firms can effectively reduce earnings management. However, it is also possible that different firms check the different customer groups. Therefore, the study further divides Big 4 accounting firms into four sub-samples: Deloitte \& Touche (Deloitte), PricewaterhouseCoopers (PwC), KPMG, and Ernst \& Young (EY). In a check of different firms by CGA to ascertain whether there are differences in earnings management, the empirical results are shown in Table 5. The empirical results show that only in the sample of Deloitte is the estimated coefficient of $C G A$ is $-0.0254(t=-2.59)$, which is significantly negatively correlated. This means that the companies audited by Deloitte have effectively suppressed earnings management and, thus, have lower earnings management behavior. In summary, of the Big 4 accounting firms, only companies audited for corporate governance by Deloitte are less likely to control earnings management. This result also implies that the audit quality provided by Deloitte is better.

\section{Conclusions}

This study is based on the companies listed on the Taiwan Stock Exchange from 2014 to 2016 and examined how their CGA affected their earnings quality. Therefore, this study calculates the financial performance based on financial data provided by discretionary accruals. However, this study further examines how CGA affects earnings management under the Big 4 accounting firms to determine its nature and to understand its causes and consequences. This is also prompted by the accelerated promotion of corporate governance policies in Taiwan across both the government and private sectors. Research data were from the Corporate Governance Appraisal - 
TWSE Corporate Governance Center and Taiwan Economic Journal (TEJ). Therefore, the empirical results show a negative correlation between CGA and earnings management. The study also found that of the Big 4 accounting firms, only Deloitte's quality of auditing was better, resulting in the control of earnings management and better financial performance.

Table 5. Corporate Governance Appraisal and Earnings Management-Big 4 accounting firms and Non-Big 4 accounting firms

\begin{tabular}{|c|c|c|c|c|c|c|c|c|c|}
\hline \multirow[b]{2}{*}{ Variables $^{\mathrm{a}}$} & \multicolumn{3}{|c|}{ Deloitte } & \multicolumn{2}{|c|}{ PwC } & \multicolumn{2}{|c|}{ KPMG } & \multicolumn{2}{|c|}{ EY } \\
\hline & $\begin{array}{c}\text { Pre } \\
\text { d. } \\
\text { Sign }\end{array}$ & Coef. & $t$-value ${ }^{\mathrm{b}}$ & Coef. & $t$-value & Coef. & $t$-value & Coef. & $t$-value \\
\hline $\begin{array}{l}\text { CONSTA } \\
N T\end{array}$ & & 0.0139 & 0.96 & -0.0293 & -1.19 & -0.0394 & $-2.28 * *$ & -0.0516 & $-2.03 * *$ \\
\hline$E M$ & - & -0.0254 & $-2.59 * * *$ & -0.0125 & -0.73 & -0.0048 & -0.38 & 0.0058 & 0.33 \\
\hline GROWTH & $?$ & 0.0058 & $2.18 * \&$ & 0.0032 & $2.16^{* *}$ & 0.0116 & $2.19 * *$ & -0.0028 & $-1.95 *$ \\
\hline ROA & $?$ & -0.0474 & -1.38 & 0.2507 & $5.22 * * *$ & 0.0391 & 0.87 & 0.0777 & 1.46 \\
\hline$L E V$ & $?$ & -0.0049 & -0.26 & 0.0597 & $1.84^{*}$ & 0.0462 & $2.07 * *$ & -0.0170 & -0.47 \\
\hline QUICK & $?$ & 0.0005 & 1.00 & 0.0004 & 0.50 & 0.0025 & $3.50 * * *$ & 0.0013 & 1.16 \\
\hline INDBOD & $?$ & -0.0494 & $-2.16^{* *}$ & -0.0999 & $-2.53 * *$ & -0.0226 & -0.71 & -0.0088 & -0.21 \\
\hline LOSS & $?$ & -0.0014 & -0.19 & -0.0054 & -0.41 & 0.0007 & 0.08 & 0.0151 & 1.03 \\
\hline $\operatorname{Adj.} R^{2}$ & & $1.28 \%$ & & $5.88 \%$ & & $2.49 \%$ & & $0.65 \%$ & \\
\hline Nobs. & 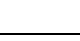 & 982 & & 650 & & 532 & & 309 & \\
\hline
\end{tabular}

The CGA data come from the Securities and Futures Institute. To accelerate the corporate governance of Taiwan listed companies and help enterprises improve market confidence, the FSC listed CGA as the key work item in 2014. The reason for its promotion is to encourage enterprises to pay more attention to corporate governance through the comparison of corporate governance in the overall market. Future target expectations include the following. (1) Through the systematic evaluation and identification of indicators, through market mechanisms such as media, feedback from shareholders, and institutional investors, and through the announcement of evaluation results, companies can actively review their internal risks and shape a corporate governance structure that is able to guide the company's stable development. (2) Companies are identified and rewarded for actively promoting corporate governance and becoming a benchmark for others. (3) Corporate governance has become a popular research topic in recent years. In addition, international organizations have successively developed evaluation indicators based on corporate governance principles and aimed at increasing Taiwan's global visibility and enhancing the international image of its capital market. In this way, enterprises and investors are encouraged to pay attention to the operation and results of the evaluation system to raise the overall corporate governance level and achieve the goals of open information, expanded participation, and better capital market quality.

\section{References}

Abbadi, S. S., Hijazi, Q. F., \& Al-Rahahleh, A. S. (2016). Corporate governance quality and earnings management: Evidence from Jordan. Australasian Accounting, Business and Finance Journal, 10(2), 54-75. https://doi.org/10.14453/aabfj.v10i2.4

Allgood, S., \& Farrell, K. (2000). The effect of CEO tenure on the relation betwe firm performance and turnover. Journal of financial research, 23(3), 373-390. https://doi.org/10.1111/j.1475-6803.2000.tb00748.x

Brian, B., Ryan, J., Casey, Jonathan, H. G., \& Dan, L. H. (2012). Exploring the Strategic Integration of Sustainability Initiatives: Opportunities for Accounting Research. Accounting Horizons, 26(2), 265-288. https://doi.org/10.2308/acch-50088

Corporate Governance Appraisal - Corporate Governance Center. Retrieved from http://cgc.twse.com.tw/evaluationCorp/listCh

Dalimunthe, D. M. J., Fadli, I. M., \& Muda, I. (2016). The Application of Performance Measurement System Model Using Malcolm Baldrige Model (MBM) to Support Civil State Apparatus. Law (ASN) Number 5 of 2014 in Indonesia. International Journal of Applied Business \& Economic Research, 14(11), 7397-7407. 
https://doi.org/10.17747/2078-8886-2013-4-42-49

DeAngelo, H., DeAngelo, L. E., \& Skinner, D. (1994). Accounting choices in troubled companies. Journal of Accounting and Economics, 17(1-2), 113-143. https://doi.org/10.1016/0165-4101(94)90007-8

Dechow, P., Sloan, R. G., \& Sweeney, A. (1995). Detecting earnings management. The Accounting Review, 70(2), 193-225.

DeFond, M. L., \& Jiambalvo, J. (1994). Debt covenant violation and manipulation of accruals, accounting choices in troubled companies. Journal of Accounting and Economics, 17(1-2), 145-176. https://doi.org/10.1016/0165-4101(94)90008-6

Defond, M., \& Hung, M. (2004). Investor protection and corporate governance: Evidence from worldwide CEO turnover. Journal of Accounting Research, 42(2), 269-312. https://doi.org/10.1111/j.1475-679X.2004.00138.x

Healy, P. M., \& Wahlen, J. M. (1999). A review of the earnings management literature and its implications for standard setting. Accounting Horizons, 13(4), 365-383. https://doi.org/10.2308/acch.1999.13.4.365

Hunton, J. E., Libby, R., \& Mazza, C. L. (2006). Financial reporting transparency \& earnings management. The Accounting Review, 81(1), 135-157. https://doi.org/10.2308/accr.2006.81.1.135

Klein, A. (2002). Audit committee, board of director characteristics, \& earnings management. Journal of Accounting \& Economics, 33(3), 375-400. https://doi.org/10.1016/S0165-4101(02)00059-9

Kothari, S. P., Leone, A. J., \& Wasley, C. E. (2005). Performance matched discretionary accrual measures. Journal of Accounting and Economics, 39(1), 163-197. https://doi.org/10.1016/j.jacceco.2004.11.002

Lel, U., \& Miller, D. (2008). International Cross-Listing, Firm Performance, and Top Management Turnover: A Test of the Bonding Hypothesis. The Journal of Finance, 63(4), 1897-1937. https://doi.org/10.1111/j.1540-6261.2008.01377.x

Lubis, A., Torong, Z. B., \& Muda, I. (2016). The Urgency of Implementing Balanced Scorecard System on Local Government in North Sumatra - Indonesia. International Journal of Applied Business \& Economic Research, 14(11), 7575-7590.

Mitton, T. (2002). A cross-firm analysis of the impact of corporate governance on the East Asian financial crisis. Journal of Financial Economics, 64(2), 215-241. https://doi.org/10.1016/S0304-405X(02)00076-4

Muda, I., Marlon, S., Erni, J., \& Abikusno, D. (2016). Critical Success Factors Downstream Palm Oil Based Small \& Medium Enterprises (SME) In Indonesia. International Journal of Economic Research, 13(8), 3531-3538.

Omar, A. F., Tony, V. Z., Keitha, D., \& Akm, W. K. (2007). Corporate governance in Bangladesh: Link between ownership and financial performance. Corporate Governance: An International Review, 15(6), 1453-1468. https://doi.org/10.1111/j.1467-8683.2007.00657.x

Reynolds, J. K., \& Francis, J. R. (2000). Does size matter? The influence of large clients on office-level auditor reporting decisions. Journal of Accounting and Economics, 30(3), 375-400. https://doi.org/10.1016/S0165-4101(01)00010-6

Schipper, K. (1989). Commentary on earnings management. Accounting Horizons, 3(4), 91-102.

Shan, Y. G. (2015). Value relevance, earnings management and corporate governance in China. Emerging Markets Review, 23, 186-207. https://doi.org/10.1016/j.ememar.2015.04.009

Volpin, P. F. (2002). Governance with poor investor protection: evidence from top executive turnover in Italy. Journal of Financial Economics, 64(1), 61-90. https://doi.org/10.1016/S0304-405X(02)00071-5

Warfield, T. D., Wild. J. J., \& Wild. K. L. (1995). Managerial ownership, accounting choices and informativeness of earnings. Journal of Accounting and Economics, 20(1), 61-92.

https://doi.org/10.1016/0165-4101(94)00393-J 
Watts, R. L., \& Zimmerman, J. L. (1986). Positive Accounting Theory. Englewood Cliffs, N. J.: Prentice-Hall.

\section{Copyrights}

Copyright for this article is retained by the author(s), with first publication rights granted to the journal.

This is an open-access article distributed under the terms and conditions of the Creative Commons Attribution license (http://creativecommons.org/licenses/by/4.0/). 